\title{
COMMENTARY
}

\section{MALAYSIA-SINGAPORE MARITIME BOUNDARY DISPUTE: SALIENT ISSUES, PROSPECTS AND CHALLENGES}

\author{
Wan Sharina Ramlah Wan A. A. Jaffri
}

\begin{abstract}
This paper looks at the latest maritime boundary dispute between Malaysia and Singapore and examines the salient issues and means of dispute settlement mechanisms open to both in resolving this quagmire. With Singapore submitting its declaration pursuant to Article 298 of the 1982 United Nations Convention on the Law of the Sea (UNCLOS 1982) on 12 ${ }^{\text {th }}$ December, 2018 in not accepting any of the procedures provided for in Section 2 of Part XV of UNCLOS 1982, this effectively means that resort to adjudicative tribunals as per the said Section is now out of the equation, and the only method(s) to pursue now would be via consensual or diplomatic channels. This paper will look at the opportunities lost from this choice made by the government of the Republic of Singapore, but, at the same time will ponder upon the possibilities of resolution of the dispute by bilateral efforts, and possibly the engagement of third parties as provided under Article 33 of the UN Charter, e.g. via the ASEAN dispute settlement mechanism. With Singapore still continuing with massive reclamation works along its coast, while at the same time not recognizing any of the official maps published by the government of Malaysia, and with the change of the diplomatic ambience brought by the new government under Prime Minister Tun Dr. Mahathir Mohamad, the prospect of a definitive resolution seems to be rather grim.
\end{abstract}

Keywords: Malaysia-Singapore maritime boundary dispute, UNCLOS 1982, dispute settlement mechanisms, ASEAN

\section{INTRODUCTION}

Disputes between Malaysia and Singapore are nothing new. Although some of them have been described as normal spats due to "sibling" rivalry, one of the most prominent ones involved questions of state's territorial sovereignty, namely the Pedra Branca / Pulau Batu Puteh Case (Sovereignty over Pedra Branca/Pulau Batu Puteh, Middle Rocks and South Ledge (Malaysia/Singapore), 2008) which went all the way up to the International Court of Justice, in which the Court awarded sovereignty of Pedra Branca to Singapore, Middle Rocks to Malaysia, while leaving the sovereignty of South Ledge to "the State in the territorial waters of which it is located". "Understandably, and expectedly, the issue of sovereignty over South Ledge has yet to be determined until today despite series of discussions being held between both governments. Malaysia had in fact submitted application for the revision and the interpretation of the judgment (the latter was with regard to the status of South Ledge) on $2^{\text {nd }}$ February 2017, however, on $28^{\text {th }}$ May 2018, had notified the Court of their decision to discontinue the 
proceedings. Interestingly, this came about after the change of government post- $14^{\text {th }}$ General Election (held on $9^{\text {th }}$ May 2018).

Another dispute which (nearly) went to an adjudicative tribunal was the 2003 Land Reclamation Case (Case Concerning Land Reclamation by Singapore In and Around the Straits of Johore, Malaysia v. Singapore, 2003) in which Malaysia had instituted arbitral proceedings against Singapore concerning the latter's land reclamation works in and around the Straits of Johore, and a request for provisional measures by the International Tribunal for the Law of the Sea (ITLOS) pending the constitution of an Arbitral Tribunal. ${ }^{2}$ In addition to its concerns of the impingement on its territorial waters brought about by the massive reclamation works carried out by Singapore in Pulau Tekong (in the northeast of Singapore) and the Tuas View Extension (in the west of Singapore), Malaysia also contended that the reclamation activities were affecting the marine environment in the Straits of Johore whereby jetties were damaged and the catch of Malaysian fishermen who made their living in the Straits of Johore was significantly reduced. As neither Malaysia nor Singapore had made any written declaration pursuant to Article 287, paragraph 1 of UNCLOS 1982 on the choices of the means of compulsory procedures in settling disputes, they were deemed to have accepted arbitration as the dispute resolution method pursuant to Article 287, paragraph 3.

The chain of events led to ITLOS issuing an Order to constitute the arbitral tribunal, and prescribing, inter alia, the establishment of a group of independent experts (GOE) to conduct a one year study on the land reclamation activities and to recommend, where appropriate, measures to deal with any adverse effects the land reclamation works may (have) caused. The GOE completed their tasks at the end of 2004 and presented their report to both governments. Prior to their meeting with the arbitral tribunal, both parties held discussions and reached an agreement of settlement which mainly provided for obligations on the part of Singapore to implement the recommendations made by the GOE. These included modifying the final design of the shoreline of its land reclamation, carrying out maintenance dredging to ensure the depth of specific areas was kept at certain levels, ensuring safe and smooth passage of ships through Kuala Johor and Calder Harbour, and paying compensation to Malaysia's fishermen as full compensation for losses due to the reclamation works. Both parties also agreed to expand the terms of reference of the Malaysia-Singapore Joint Committee on the Environment (MSJCE) to include, inter alia, exchanging information and discuss matters affecting their respective environments, and to undertake monitoring activities. This settlement agreement was adopted as final and binding, and the case was accordingly terminated and withdrawn from the arbitral tribunal proceedings.

Both Malaysia and Singapore somehow managed to get embroiled in yet another maritime dispute when in October 2018, Malaysia published a Federal Government Gazette declaring the alterations of port limits for Johor Bahru Port (Federal Government Gazette P.U.(B) 587 : Declaration of Alteration of Port Limits for Johor Bahru Port, dated $25^{\text {th }}$ October, 2018) ${ }^{3}$ to which Singapore protested - calling the declaration unilateral and claiming that the new port limits were encroaching upon their territorial waters. Malaysia responded by stating that the claim made by Singapore was "inaccurate", in the sense that the latter had never declared a maritime boundary in that area and as such they were in no position to claim that their territorial waters had been "encroached" by Malaysia. Additionally, Malaysia also argues 
that land reclamation works carried out by Singapore in the disputed area does not give them a new baseline from which their maritime boundaries - territorial waters included, are measured.

We may gauge the path this dispute is heading by looking at several of its salient issues, and also by analyzing the prospects and challenges which both parties may have to face along the way.

\section{SALIENT ISSUES, PROSPECTS AND CHALLENGES}

Some of the salient issues, challenges and prospects which we could put forth with regard to this latest maritime boundary dispute between Malaysia and Singapore are as follows -

Firstly, Singapore has never acknowledged Malaysia's official map defining its territorial waters and continental shelf published in 1979. The delimitation of the territorial waters in this latest disputed sector had never really been mutually and officially determined by both states despite them signing an agreement in 1995 which followed the 1927 Straits Settlement and Johore Territorial Waters Agreement. Both these agreements essentially corresponded with the alignment of the deepest points in the Straits of Johore - albeit the 1995 agreement had adopted the use of geographical coordinates, instead of the thalweg method as prescribed in the 1927 agreement. However, the area under the latest dispute apparently falls outside the points agreed upon in the 1995 agreement, and has not been determined. As such, Malaysia had always fallen back to the 1979 map to fill in the lacunae. Hypothetically, if we were to combine or merge both methods in current times, this would proof to be a redundant effort as silts and other deposits from the reclamation works (not necessarily by just Singapore, but may also be by Malaysia), would definitely have changed the coordinates of the deepest points in the area. The maritime boundary in this sector would continue to be a running target so long as Singapore continues with its reclamation projects at the current rate.

Secondly, the extensive reclamation works carried out in the area had also meant that Singapore's coastline had been altered significantly. However, this does not give Singapore the right to claim a new baseline from which their maritime boundaries are to be measured. Land reclamation does not extend the baseline of states, which in turn also means that it does not extend the state's territorial waters. It is imperative for Singapore to identify its original baseline (as may have been acquiesced, if at all, by Malaysia at some point post-1995) and limit its reclamation works within what is allowed under the provisions of UNCLOS 1982 with regards to rights of states within their territorial waters.

Thirdly, it is interesting to note that Malaysia's Prime Minister Tun Dr. Mahathir Mohamad, while having responded diplomatically, has indicated that there is a need to settle disputes between the two states based on legal rights and provisions (this would also include the current dispute over the airspace for the landing approach of Singapore's Seletar Airport). This would seem that Malaysia is rather keen to pursue an adjudicative method, instead of a consensual or voluntary process of dispute settlement. Diplomatic methods in solving disputes between the two states had proven how Malaysia had been short-changed time and time again, and understandably, Tun Dr. Mahathir Mohamad sees the need to change this. However, this 
path may not be possible for the latest dispute as Singapore had, on $12^{\text {th }}$ December 2018 , submitted its declaration under Article 298 of the 1982 United Nations Convention on the Law of the Sea (UNCLOS 1982) in not accepting any of the procedures provided for in Section 2 of Part XV of UNCLOS 1982. This effectively means that resort to adjudicative tribunals as per the said Section is now out of the equation, i.e., recourse to ITLOS, the International Court of Justice, Arbitration Tribunal and Special Arbitration Tribunal which could have led to a binding decision based on legal principles are no longer open to the disputing states, and the only method(s) to pursue now would be via consensual or diplomatic channels.

Fourthly, would this latest dispute be purely academic if the Arbitration Tribunal in the 2003 Land Reclamation Case had been convened and a binding decision with regard to limits of Singapore's reclamation works and/or limits of the territorial waters of both States had been determined then? In that case, in its Order pursuant to Malaysia's request for provisional measures for Singapore to suspend all land reclamation activities in both Pulau Tekong and Tuas pending the constitution of an arbitral tribunal, ITLOS had somehow decided to not deliberate on works carried out in the Tuas Sector, which is the area where the latest maritime dispute lies. One of the reasons provided was that ITLOS did not consider it appropriate in the circumstances to prescribe provisional measures with respect to the land reclamation by Singapore in Tuas as even though Malaysia had claimed that Singapore had impinged on areas of Malaysia's territorial waters by its land reclamation works in the sector of Tuas, the existence of Malaysia's claim to an area of territorial sea was not, per se, a sufficient basis for the prescription of provisional measures requested by Malaysia. In addition, it was stated that there was no urgency for a provisional measure to be put in place with regard to the reclamation works in the Tuas Sector. Things could have taken a different path if issues pertaining to this sector had been considered and included in the Order issued by ITLOS, and thereafter the case was submitted for adjudication by the Arbitration Tribunal as per Malaysia's original application. But, alas - that was not meant to be.

Fifthly, it is interesting to note that Singapore was open for previous disputes to be submitted to adjudicative tribunals - namely, the Pedra Branca / Pulau Batu Puteh Case to the ICJ, and the 2003 Land Reclamation Case to the Arbitration Tribunal under the provisions of UNCLOS 1982 (even though as mentioned earlier, the case was terminated and settled by an agreement signed by both parties before the arbitration tribunal was scheduled to convene). What has changed? Are the stakes too high this time around? Should issues pertaining to states' territorial sovereignty which have reached a stalemate not be settled once and for all through adjudicative methods? It is highly unlikely for both states to negotiate or give in or compromise on their territorial sovereignty. A consensual or a diplomatic approach is definitely not the way to go. This is even more so when, ironically, Singapore was the party who has made strong claims that Malaysia's act is a "blatant provocation and a serious violation of Singapore's sovereignty and international law" (Tay, 2018). ${ }^{4}$ All the more reason for the city state to opt for and resort to an adjudicative tribunal to deliberate and make definitive decisions on the maritime boundaries based on international law and principles, rather than banking on diplomatic measures to provide a sound legalistic outcome.

Sixthly, the diplomatic and voluntary measures which come to mind would be those provided under Section 1 of Part XV UNCLOS 1982. These are essentially methods provided 
by Article 33 of the UN Charter on Pacific Settlement of Disputes, i.e., seeking solution through negotiation, enquiry, mediation, conciliation, arbitration, judicial settlement, resort to regional agencies or arrangements, or other peaceful means of their own choice. Of course, subjecting the dispute to an arbitration tribunal and the ICJ for a judicial settlement are out of the question at this point. Which of the remaining peaceful dispute settlement methods would be mutually agreeable to both states then? More importantly, which of the methods would be the most effective and successful in settling this stalemate given the fact that the exact same methods had been applied and adopted by the parties for years in almost all of their disputes without any significant and / or positive outcomes. Having said that, resort to adjudicative tribunals may not necessarily have led to a full-fledged, final and all-encompassing judgment either. This was quite evident in both the Land Reclamation and South Ledge cases.

Seventhly, what types of regional dispute settlement procedures and mechanisms are open to Malaysia and Singapore under the ASEAN umbrella, if any? Would the parties be open to submit their dispute to an adjudicative tribunal outside of those provided under Section 2 of UNCLOS 1982? Alas, true to the "ASEAN Way", ASEAN dispute settlement framework does not include any compulsory jurisdiction mechanisms even if both Singapore and Malaysia were to decide to resort to one. The framework for settlement of disputes for ASEAN is to be found in Chapter VIII of the ASEAN Charter, whereby disputes not relating to the interpretation and application of any ASEAN instrument are to be resolved in accordance with the 1976 Treaty of Amity and Cooperation in Southeast Asia (TAC) (ASEAN Charter, 2007). ${ }^{5}$ Chapter IV of the TAC covers the Pacific Settlement of Disputes. The 2007 ASEAN Charter resonates the 1976 TAC in that it provides for the first line in settling disputes to be in the forms of dialogues, consultation and negotiation (ASEAN Charter 2007). ${ }^{6}$ The mechanism under TAC consists of the High Council - comprising of one representative at ministerial level from each ASEAN member states together with representatives of Non-ASEAN members which are directly involved in the dispute, whereby in the eventualities of unsuccessful negotiations, the High Council is to recommend appropriate means of settlement such as the use of good offices, inquiry, conciliation or mediation, i.e. in engaging a third party in different capacities to assist in settling the dispute (Treaty of Amity and Cooperation in Southeast Asia, 1976). Malaysia and Singapore may request the Chairman or the Secretary-General of ASEAN to provide his good office, or to take the role of a conciliator or a mediator (ASEAN Charter, 2007). ${ }^{7}$ Both Malaysia and Singapore must agree for TAC mechanisms to be applicable. An added feature as a fallback is that TAC does allow member states to take recourse to modes of settlement as provided by Article 33 of the UN Charter - this only amplifies the Catch 22 situation in settling this maritime boundary dispute.

\section{CONCLUSION}

The latest maritime boundary dispute between Malaysia and Singapore has its roots from issues which had been broiling for years. Bilateral methods had proven to only provide temporary resolution before new related disputes would be inflamed again. Most cases have seen Malaysia being rather short-changed through bilateral dispute resolution means, and Singapore does not seem to be open to revisit and renegotiate new resolutions in light of new development and circumstances. The nature of a negotiation is that there must be some gives 
and some takes. As long as one party only takes, negotiations are doomed for failure. Maritime boundaries are matters pertinent to States territorial sovereignty, and should be resolved by adjudicative tribunals - even more so in stalemate situations such as this. As long as Singapore is averse to submitting this dispute to compulsory procedures which promise a final and binding decision, there seems to be no light at the end of the tunnel.

\section{REFERENCES}

1 Sovereignty over Pedra Branca/Pulau Batu Puteh, Middle Rocks and South Ledge (Malaysia/Singapore), Judgment, I.C.J. Reports 2008, p.12.

2 Case Concerning Land Reclamation by Singapore In and Around the Straits of Johore (Malaysia v. Singapore), Provisional Measures, ITLOS Case No 12, ICGJ 345 (ITLOS 2003), 8th October 2003, International Tribunal for the Law of the Sea [ITLOS].

3 Federal Government Gazette P.U.(B) 587 : Declaration of Alteration of Port Limits for Johor Bahru Port, dated Oct 25, 2018 (the "Gazette Notification"), Port Circular No 88/2018 dated Nov 11, 2018 ("PC $88 / 2018$ ").

${ }^{4}$ Tay, C. (2018, December 6), "Singapore extends port limits off Tuas, overlaps JB Port limits", Retrieved from http://www.theedgemarkets.com/article/singapore-extends-port-limits-tuas-overlaps-jb-portlimits\#.XFLT RL16PA.email 15 December 2018.

ASEAN Charter, 2007, Article 24(2).

6 ASEAN Charter, 2007, Article 22(1).

7 ASEAN Charter, 2007, Article 23(2). 